\title{
PREDICTION OF NEONATAL JAUNDICE BY STUDY OF CORD BLOOD BILIRUBIN AND SERUM BILIRUBIN AT 24 HOURS OF LIFE
}

\author{
Sindhura Vinnakota ${ }^{1}$, Naveen Kumar Mallineni², Ravi Kumar Chodavarapu³, Y. Asha ${ }^{4}$ \\ 1Medical Officer, Department of Paediatrics, Special New Born Care Unit (SNCU), King George Hospital, Visakhapatnam, \\ Andhra Pradesh, India. \\ ${ }^{2}$ Civil Assistant Surgeon, Department of Plastic Surgery, Visakha Institute of Medical Sciences (VIMS), Visakhapatnam, \\ Andhra Pradesh, India. \\ 3 Professor, Department of Paediatrics, Dr. PSIMS \& RF Hospital, Vijayawada, Andhra Pradesh, India. \\ ${ }^{4}$ Consultant Paediatrician, Department of Paediatrics, Amma Children Hospital, Ongole, Andhra Pradesh, India.
}

\begin{abstract}
\section{BACKGROUND}

Jaundice is yellowish discolouration of the skin, the mucous membranes or the eyes. It is caused by high levels of the chemical bilirubin in blood, a by-product of destruction of old red blood cells. A newborn baby's liver is not fully matured, so jaundice is common during a baby's first few days of life ${ }^{1}$ Since bilirubin is potentially toxic to the central nervous system, early detection and appropriate management of neonatal jaundice (NNJ) is of paramount importance ${ }^{2}$. Hence early detection of neonatal jaundice is an important issue. The present study was conducted to find out the critical value of serum bilirubin in the cord blood and at $24 \mathrm{hrs}$. in predicting the subsequent development of hyperbilirubinemia in healthy newborn babies.
\end{abstract}

\section{METHODS}

Cord blood sample and blood sample at 24 hours were collected from all 200 babies. After 24 hours and up to $5^{\text {th }}$ post-natal day, blood samples for serum bilirubin estimation were taken from those babies who were clinically suspected to be having jaundice.

\section{RESULTS}

Total serum bilirubin $>2.3 \mathrm{mg} / \mathrm{dl}$ has sensitivity of $75.3 \%$ (95\% CL 65.2\% to 83.6\%), specificity of $81.3 \%$ (95\% CL 72.6\% to $88.2 \%$ ), positive predictive value of 77.8 (67.8 to 85.9 ), negative predictive value of $79.1 \%$ ( $70.3 \%$ to 86.3 ). The diagnostic ability of TSB at $24 \mathrm{hrs}$. to predict the need for phototherapy shows that TSB > $5.3 \mathrm{mg} / \mathrm{dl}$, has sensitivity of $87 \%$ (95\% CL 78.5\% to $93.2 \%$ ), specificity of $67.3 \%$ (95\% CL 57.5\% to 76\%), positive predictive value of 69.8 (60.6 to 78.0), negative predictive value of 85.7 (87.5 to 85.4).

\section{CONCLUSIONS}

The time to reach maximum total serum bilirubin level after birth is $3^{\text {rd }}$ postnatal day in our study. So, the baby in need of phototherapy has to be identified earlier to $3^{\text {rd }}$ postnatal day. A total serum bilirubin level prior to $3^{\text {rd }}$ day which can predict the later need of photo-therapy in a given baby will have clinical utility. The optimum cut off value of total serum bilirubin in cord blood which can predict the need for phototherapy is $>2.3 \mathrm{mg} / \mathrm{dl}$ and value of total serum bilirubin at 24 hrs which can predict the need for phototherapy is $>5.3 \mathrm{mg} / \mathrm{dl}$. So, these at-risk babies should be observed carefully for the need of phototherapy.

HOW TO CITE THIS ARTICLE: Vinnakota S, Mallineni NK, Chodavarapu RK, et al. Prediction of neonatal jaundice by study of cord blood bilirubin and serum bilirubin at 24 hours of life. J. Evolution Med. Dent. Sci. 2019;8(13):1039-1045, DOI: $10.14260 /$ jemds $/ 2019 / 230$

\section{BACKGROUND}

Jaundice is yellowish discolouration of the skin, the mucous membranes or the eyes. Jaundice comes from the French word "Jaune" which means yellow. It is also known as icterus. When a baby has jaundice, either too much bilirubin is being produced or the liver does not get rid of it quickly enough. A newborn baby's liver is not fully matured, so jaundice is common during a baby's first few days of life. ${ }^{1}$ Since bilirubin is potentially toxic to the central nervous system, early detection and appropriate management of neonatal jaundice (NNJ) is of paramount importance. ${ }^{2}$ Hence early detection of neonatal jaundice is an important issue.

'Financial or Other Competing Interest': None.

Submission 04-03-2019, Peer Review 24-03-2019,

Acceptance 27-03-2019, Published 01-04-2019.

Corresponding Author:

Dr. Naveen Kumar Mallineni,

Flat No. 102, ELRS Residency,

Beside Vaishnavi Hospital, Krishna Nagar,

Visakhapatnam-530002, Andhra Pradesh, India.

E-mail: naveen.mallineni@gmail.com

DOI: $10.14260 /$ jemds $/ 2019 / 230$ has become a common practice, because of medical and social reasons and economic constrains. ${ }^{3}$ Thus, the recognition, follow up and early treatment of jaundice has become more difficult as a result of early discharge from the hospital. The prevention of bilirubin encephalopathy is based on the detection of infants at risk of developing significant hyperbilirubinaemia and early treatment of this condition. Therefore, it is difficult to predict which infants are at increased risk for significant and relatively late hyperbilirubinaemia. ${ }^{4}$ And as such, from the obvious need to design and implement a follow up programme, the present study was conducted to find out the critical value of serum bilirubin in the cord blood and at $24 \mathrm{hrs}$ in predicting the subsequent development of hyperbilirubinemia in healthy newborn.

\section{Epidemiology of Neonatal Jaundice}

Neonatal hyperbilirubinemia is a commonly diagnosed phenomenon in the Neonate with potential serious consequences. Recent studies have estimated incidence of $6 \%$ to $10 \%$ in the general population.5,6 Jaundice is the most 
common condition in newborns that requires medical attention. About $50 \%$ to $70 \%$ of term babies and $80 \%$ of preterm babies develop jaundice in the first week of life. ${ }^{7}$ Jaundice usually appears 2 to 4 days after birth and resolves 1 to 2 weeks later without the need for treatment. The incidence of hyperbilirubinaemia varies. A study in the UK and Ireland showed an incidence of severe hyperbilirubinaemia (Maximum unconjugated serum bilirubin $\geq 510$ micro-mol/L [29.8 mg/dL]) of 7.1 per $100,000.8$ A study in Denmark showed an incidence of extreme hyperbilirubinaemia (492 micro-mol/L [28.8 $\mathrm{mg} / \mathrm{dL}])$ of 25 per $100,000.9^{9}$ In the US, severe hyperbilirubinaemia (Total serum bilirubin $>95$ th percentile) occurs in $8 \%$ to $9 \%$ of neonates during the first week; approximately $4 \%$ after 72 hours of life. 10

\section{Risk Factors for Hyperbilirubinemia in Newborns11,12,13 Maternal Factors}

- Blood type $\mathrm{ABO} / \mathrm{Rh}$ incompatibility.

- $\quad$ Breast feeding.

- Diazepam, Oxytocin.

- Ethnicity: Asian, Native American.

- Maternal illness: Gestational Diabetes.

\section{Neonatal Factors}

- Birth trauma: cephalohematoma, cutaneous bruising.

- Instrumented delivery.

- Drugs: Sulfisoxazole, Erythromycin.

- Excessive weight loss after birth.

- Infections: TORCH.

- Infrequent feedings.

- Male gender.

- Polycythaemia.

- Prematurity.

- Previous sibling with Hyperbilirubinemia.

\section{Aims and Objectives}

1. To identify the post-natal age at which the total serum bilirubin \{T.S.B. reaches its peak.

2. To observe differences in T.S.B. between babies that needed phototherapy and did not need it, from birth to five days after birth.

3. To find the phototherapy need predictive ability of T.S.B. values those are lower and earlier to the peak T.S.B.

\section{METHODS}

\section{Study Design}

Longitudinal comparative study.

\section{Study Period}

From January 2013 to February 2014 with a total period of 13 months.

\section{Study Setting}

Study was conducted at Dr. Pinnamaneni Siddhartha Institute of Medical Sciences, Gannavaram, Vijayawada.

\section{Sample}

200 newborn babies born in Dr. PSIMS \& RF.

\section{Inclusion Criteria}

Healthy new born babies born in our hospital from June 2011 to August 2013.

\section{Exclusion Criteria}

Sick babies are excluded. Any newborn requiring admission in our newborn intensive care unit like.

1. Preterm babies $<34$ weeks.

2. Newborns with respiratory distress (rate $>60 / \mathrm{min}$ ).

3. Babies with congenital anomalies.

4. Babies with maternal infection.

5. Birth weight $<2500 \mathrm{~g}$ and weight $>4000 \mathrm{~g}$.

6. Babies with severe birth asphyxia were excluded.

\section{Method of Sample Collection}

Cord blood sample and blood sample at 24 hours were collected for all the 200 babies to identify their ability to distinguish a baby who needs phototherapy from a baby who does not need phototherapy in next 5 days of life. After 24 hours and up to 5 th post-natal day blood samples for serum bilirubin estimation were taken for those babies who were clinically suspected to be having jaundice. Serum bilirubin is measured by spectrophotometry by Van den Bergh test

\section{Statistical Analysis}

Data were documented in the case record form and converted into electronic data base using Microsoft excel 2007. Statistical analysis was done using Epi info 7.1.2.0 of Centre for Disease Control, USA and Medical 12.7.5 Belgium.

Numerical continuous variables were summarized as mean or median with corresponding 95\% Confidence limit, standard deviation and range. Normality of distribution was tested by D'Agostins - Pearson test which computes a single P value for the combination of coefficients of Skewness and kurtosis. As the continuous variables are having a nonnormal distribution despite logarithmic transformation, median and corresponding 95\% confidence limit are considered for further statistical analysis. The Mann Whitney test is used to test the significance of the difference between medians of the two independent samples.

Serial measurement analysis was done to know the time at which mean total serum bilirubin reached its maximum value. The degree of association between total serum bilirubin values from birth to $5^{\text {th }}$ postnatal day was analysed by Spearman's rank correlation as the distribution of means of total serum bilirubin values are non-normal in distribution.

Phototherapy predictive utility of total serum bilirubin values of different times which identifies a baby that is likely to need phototherapy was evaluated with ROC curve analysis. Categorical variables were summarized by frequency, percentage and $95 \%$ confidence limit. 
RESULTS

\begin{tabular}{|c|c|c|c|c|c|c|c|c|c|}
\hline Variable & $\begin{array}{c}\text { Sample } \\
\text { Size }\end{array}$ & Lowest & Highest & EAN & 95\% CL Mean & Median & $\begin{array}{l}95 \% \text { CL } \\
\text { Median } \\
\end{array}$ & D & Distribution \\
\hline GA & 200 & 33 & 41 & 8.75 & $38.55-38.94$ & 39 & $39-39$ & .42 & $\begin{array}{c}(\mathrm{P}<0.0001) \text { reject } \\
\text { normality }\end{array}$ \\
\hline GA Term & 184 & 37 & 41 & 9.05 & 38.91- 39.19 & 39.00 & $39.0-39$ & .97 & $\begin{array}{c}(\mathrm{p}=0.0222) \text { reject } \\
\text { normality }\end{array}$ \\
\hline GA Preterm & 16 & 33 & 36 & 5.19 & $34.74-35.63$ & 35 & $35-36$ & .83 & $\begin{array}{c}(\mathrm{P}=0.0341) \mathrm{reject} \\
\text { normality }\end{array}$ \\
\hline Birth WT & 200 & 1.5 & 3.8 & .77 & $2.75-2.8$ & 2.75 & $2.75-2.8$ & .40 & $\begin{array}{c}\mathrm{W}=0.9569 . \text { reject } \\
\text { normality } \\
(\mathrm{P}<0.0001)\end{array}$ \\
\hline BW Term & 184 & 2.0 & 3.8 & .88 & $2.78-2.88$ & 2.75 & 2.75- 2.8 & .33 & $\begin{array}{c}\mathrm{W}=0.935 \text { Reject } \\
\text { normality( } \mathrm{p}= \\
0.0014)\end{array}$ \\
\hline BW Preterm & 16 & 1.5 & 3.2 & .09 & $1.79-2.38$ & 1.88 & $1.6-2.64$ & .55 & $\begin{array}{c}\mathrm{W}=0.8756 \text { reject } \\
\text { normality } \\
(\mathrm{P}=0.332)\end{array}$ \\
\hline & \multicolumn{2}{|c|}{ Group } & \multicolumn{2}{|c|}{ Frequency } & \multicolumn{2}{|c|}{ Percent } & \multicolumn{3}{|c|}{ 95\% Confidence Limits } \\
\hline \multirow{2}{*}{ Sex } & \multicolumn{2}{|c|}{ Female } & \multicolumn{2}{|c|}{89} & \multicolumn{2}{|c|}{$44.5 \%$} & \multicolumn{2}{|c|}{$37.5 \%$} & $51.7 \%$ \\
\hline & \multicolumn{2}{|c|}{ Male } & \multicolumn{2}{|c|}{111} & \multicolumn{2}{|c|}{$55.5 \%$} & \multicolumn{2}{|c|}{$48.3 \%$} & $62.5 \%$ \\
\hline \multirow{2}{*}{ Maturity } & \multicolumn{2}{|c|}{ Preterm } & \multicolumn{2}{|c|}{16} & \multicolumn{2}{|c|}{$8.00 \%$} & \multicolumn{2}{|l|}{$4.6 \%$} & $12.7 \%$ \\
\hline & \multicolumn{2}{|c|}{ Term } & \multicolumn{2}{|c|}{184} & \multicolumn{2}{|c|}{$92 \%$} & \multicolumn{2}{|c|}{$87.3 \%$} & $95.36 \%$ \\
\hline
\end{tabular}

In this study of 200 newborn babies the median gestational age is 39 weeks, $95 \%$ confidence limit is $39-39$ weeks and the range is 33-41 weeks. Out of 200 neonates, 184 (92\%, 95\% CI 87.3\% to $95.4 \%)$ are full term and $16(8 \%, 95 \% 4.6 \%$ to $12.7 \%)$ are preterm, indicating predominance of full-term babies. Median gestational age of full-term group is 39 weeks, $95 \%$ confidence limit is $39-39$ weeks and range is $37-41$ weeks. Median gestational age of preterm group is 35 weeks, $95 \%$ confidence limit is $35-36$ weeks and range is $33-36$ weeks. [Table 1] Median birth weight of whole group of 200 babies is $2.75 \mathrm{Kg}$ (95\% CL $2.75 \mathrm{Kg}$ to 2.8 $\mathrm{Kg}$, range $1.5 \mathrm{Kg}$ to $3.8 \mathrm{Kg}$ ). Median birth weight of term group is $2.75 \mathrm{Kg}$ (95\% CL $2.75 \mathrm{Kg}-2.8 \mathrm{Kg}$, range $2 \mathrm{Kg}-3.8 \mathrm{Kg}$ ). Median birth weight of preterm group is $1.87 \mathrm{Kg}$ (95\% CL $1.6 \mathrm{Kg}-2.6 \mathrm{Kg}$, range $1.5 \mathrm{Kg}-3.2 \mathrm{Kg}$ ). Out of 200 babies, males are 111 [55.5\%, 95\% CL 48.32\%- 62]

\begin{tabular}{|c|c|c|c|c|c|c|}
\hline $\begin{array}{c}\text { TSB at } \\
\text { Postnatal } \\
\text { Age }\end{array}$ & $\begin{array}{c}\text { Phototherapy } \\
\text { Yes }\end{array}$ & $\begin{array}{c}\text { Phototherapy } \\
\text { No }\end{array}$ & $\begin{array}{c}\text { Mann } \\
\text { Whitney U U Score } \\
\text { (Corrected } \\
\text { for Ties) }\end{array}$ & Probability & $\begin{array}{c}\text { TSB at which Standard Guidelines } \\
\text { Recommend Phototherapy } \\
\text { (in Low Risk Healthy Infants) }\end{array}$ \\
\hline $\begin{array}{c}\text { TSB CORD } \\
\text { (mg/dl) }\end{array}$ & $2.8(2.6-2.9)$ & $1.9(1.8-2)$ & 1858 & 7.65 & $\mathrm{P}<0.0001$ & 7 \\
\hline $\begin{array}{c}\text { TSB at 24 hrs } \\
\text { (mg/dl) }\end{array}$ & $6.2(6-6.4)$ & $4.6(4.4-5)$ & 1748 & 7.911 & $\mathrm{P}<0.0001$ & 12 \\
\hline $\begin{array}{c}\text { TSB on 3rd day } \\
(\mathrm{mg} / \mathrm{dl})\end{array}$ & $18(18-19)$ & $12(11-13)$ & 140 & 8.45 & $\mathrm{P}<0.0001$ & 15 \\
\hline $\begin{array}{c}\text { TSB 4th day } \\
(\mathrm{mg} / \mathrm{dl})\end{array}$ & $17(16-17)$ & $12(11-13)$ & 110 & 7.929 & $\mathrm{P}<0.0001$ & 17.5 \\
\hline $\begin{array}{c}\text { TSB 5th day } \\
\text { (mg/dl) }\end{array}$ & $13(12-13)$ & $11.35(11-13)$ & 987.5 & 2.324 & $\mathrm{P}=0.0201$ & 20 \\
\hline
\end{tabular}

Table 2. Serum Bilirubin Differences Since Birth Between Phototherapy Needed and Not Needed Babies

Table 2 shows relationship between Serum Bilirubin levels and the management with Phototherapy need or not needed. The median serum bilirubin from birth to $5^{\text {th }}$ day of life is significantly more in the group of babies who needed phototherapy compared to those babies who did not need phototherapy, even before the indication for phototherapy is evident at that time.

\begin{tabular}{|c|c|c|c|c|c|c|}
\hline \multicolumn{3}{|c|}{ Variable Y (data) } & \multicolumn{4}{|c|}{ Total Serum Bilirubin } \\
\hline \multicolumn{3}{|c|}{ Variable X (time) } & \multicolumn{4}{|c|}{ Day of Bilirubin } \\
\hline \multicolumn{3}{|c|}{ Variable for cases } & \multicolumn{4}{|c|}{ Case } \\
\hline \multicolumn{3}{|c|}{ Summary measure of interest } & \multicolumn{4}{|c|}{ Time to reach maximum } \\
\hline Group & $\mathrm{N}$ & Mean & $95 \% \mathrm{CI}$ & SD & Median & $95 \% \mathrm{CI}$ \\
\hline (All cases) & 200 & 3.415 & 3.287 to 3.543 & 0.915 & 3.000 & 3.000 to 3.000 \\
\hline
\end{tabular}

Serial measurement analysis showed that in our study, the median time for total serum bilirubin to reach maximum is 3 days. 


\begin{tabular}{|c|c|c|c|c|c|}
\hline Time of Bilirubin & TSB Range (mg/d) & +LR Range & Probability (PPV) Range & -LR Range & Probability (NPV) Range \\
\hline \multirow{4}{*}{ Cord Blood at Birth } & $\geq 0.5$ to $>1.0$ & 1 to 1.5 & 46.5 to 50 & 0.00 to 0.077 & 100 to 93.7 \\
\cline { 2 - 6 } & $>1.1$ to $>1.6$ & 1.16 to 1.52 & 50.3 to 56.9 & 0.072 to 0.17 & 94.1 to 87.2 \\
\cline { 2 - 6 } & $>1.7$ to $>2.2$ & 1.52 to 3.66 & 57 to 76.1 & 0.19 to 0.31 & 85.7 to 78.7 \\
\cline { 2 - 6 } & $>2.3$ & 4.03 & 77.8 & 0.3 & 79.1 \\
\hline \multirow{3}{*}{ At $24 \mathrm{hrs}$} & $\geq 2.4$ to $>3.5$ & 1 to 1.15 & 46.5 to 50 & 0.00 to 0.14 & 100 to 88.9 \\
\cline { 2 - 6 } & $>3.6$ to $>4.5$ & 1.22 to 1.82 & 51.4 to 61.3 & 0.11 to 0.13 & 91.3 to 89.7 \\
\cline { 2 - 6 } & $>4.6$ to $>5.2$ & 1.92 to 2.52 & 62.5 to 68.6 & 0.16 to 0.2 & 87.5 to 85.4 \\
\cline { 2 - 6 } & \multicolumn{7}{|c|}{ Table 4. Phototherapy Predictive Ability of TSB Ranges } & 85.7 \\
\hline
\end{tabular}

\begin{tabular}{|c|c|c|c|c|c|c|c|c|c|c|}
\hline 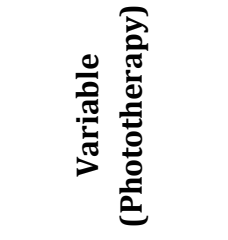 & 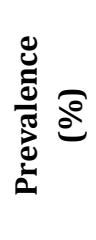 & 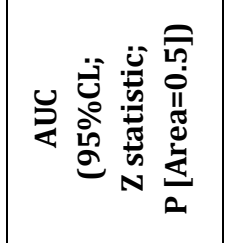 & 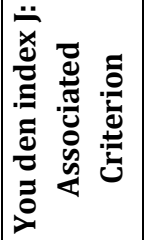 & 苞 & 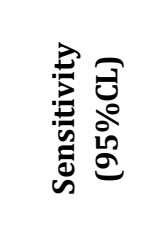 & 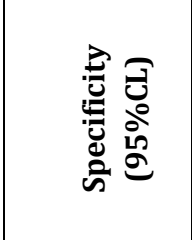 & 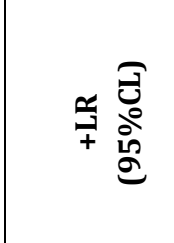 & 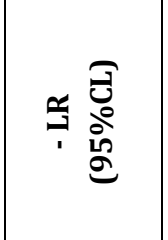 & 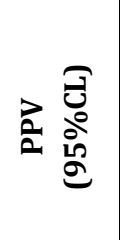 & 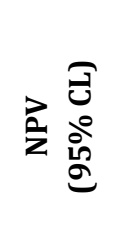 \\
\hline $\begin{array}{l}\text { TSB Cord Blood } \\
\text { (Yes: 93; } \\
\text { No: 107) }\end{array}$ & 46.5 & \begin{tabular}{|c|}
0.813 \\
$(0.752$ to 0.865 \\
10.153 \\
$\mathrm{P}<0.0001)$
\end{tabular} & $\begin{array}{c}0.5658: \\
>2.3\end{array}$ & $>2.3$ & $\begin{array}{c}75.27 \\
(65.2- \\
83.6)\end{array}$ & $\begin{array}{c}81.31 \\
(72.6-88.2)\end{array}$ & $\begin{array}{c}4.03 \\
(2.7-6.1)\end{array}$ & $\begin{array}{c}0.30 \\
(0.2-0.4)\end{array}$ & $\begin{array}{c}77.8 \\
(67.8- \\
85.9)\end{array}$ & $\begin{array}{l}79.1 \\
(70.3- \\
86.3)\end{array}$ \\
\hline $\begin{array}{l}\text { TSB at } 24 \text { hours } \\
\text { (Yes: 93; } \\
\text { No: 107) }\end{array}$ & 46.5 & $\begin{array}{c}0.824 \\
(0.764 \text { to } \\
0.874) ; \\
10.890 ; \\
\mathrm{P}<0.0001\end{array}$ & $\begin{array}{c}0.5439 \\
>5.3\end{array}$ & $>5.3$ & $\begin{array}{c}87.10 \\
\text { (78.5 to } \\
93.2)\end{array}$ & $\begin{array}{c}67.29 ; \\
(57.5 \text { to } 76.0)\end{array}$ & $\begin{array}{c}2.66 \\
(2.0 \text { to } 3,5)\end{array}$ & $\begin{array}{c}0.19 \\
(0.1 \text { to } 0.3)\end{array}$ & $\begin{array}{c}69.8 \\
(60.6 \text { to } \\
78.0)\end{array}$ & $\begin{array}{c}85.7 \\
\text { (76.4 to } \\
92.4)\end{array}$ \\
\hline $\begin{array}{l}\text { TSB 3rd day } \\
\text { (Yes: } 85 ; \\
\text { No= 42) }\end{array}$ & 66.9 & $\begin{array}{c}0.961 \\
(0.911 \text { to } \\
0.987) ; \\
22.922 ; \\
\mathrm{P}<0.0001\end{array}$ & $\begin{array}{c}0.9053 \\
>14.5\end{array}$ & $>14$ & $\begin{array}{c}96.47 \\
(90.0 \text { to } \\
99.3)\end{array}$ & $\begin{array}{c}92.86 \\
(80.5 \text { to } 98.5)\end{array}$ & $\begin{array}{c}13.51 \\
(4.5 \text { to } 40.2)\end{array}$ & $\begin{array}{c}0.038 \\
(0.01 \text { to } \\
0.1)\end{array}$ & $\begin{array}{c}96.5 \\
(90.0 \text { to } \\
99.3)\end{array}$ & $\begin{array}{c}92.9 \\
(80.3 \text { to } \\
98.5)\end{array}$ \\
\hline $\begin{array}{l}\text { TSB 4th day } \\
\text { (Yes: 72; } \\
\text { No: } 38 \text { ) }\end{array}$ & 65.5 & $\begin{array}{c}0.960 \\
(0.904 \text { to } \\
0.988) \\
28.958 ; \\
\mathrm{P}<0.0001\end{array}$ & $\begin{array}{l}0.8114 \\
\quad>13\end{array}$ & $>13$ & $\begin{array}{c}91.67 \\
(82.7 \text { to } \\
96.9)\end{array}$ & $\begin{array}{c}89.47 \\
(75.2 \text { to } 97.1)\end{array}$ & $\begin{array}{c}8.71 \\
(3.4 \text { to } 22.1)\end{array}$ & $\begin{array}{c}0.093 \\
(0.04 \text { to } \\
0.2)\end{array}$ & $\begin{array}{c}94.3 \\
(86.0 \text { to } \\
98.4)\end{array}$ & $\begin{array}{c}85 \\
\text { (70.2 to } \\
94.3)\end{array}$ \\
\hline $\begin{array}{l}\text { TSB } 5^{\text {th }} \text { day } \\
\text { (Yes: } 80 ; \\
\text { No: } 34 \text { ) }\end{array}$ & 70.2 & $\begin{array}{c}0.637 \\
(0.542 \text { to } \\
0.725) ; \\
2.415 ; \\
\mathrm{P}=0.0157\end{array}$ & $\begin{array}{c}0.2169 \\
>11.7\end{array}$ & $>8$ & $\begin{array}{c}98.75 \\
(93.2 \text { to } \\
100.0)\end{array}$ & $\begin{array}{c}11.76 \\
\text { (3.3 to } 27.5)\end{array}$ & $\begin{array}{c}1.12 \\
\text { (1.0 to } 1.3)\end{array}$ & $\begin{array}{c}0.11 \\
(0.01 \text { to } \\
0.9)\end{array}$ & $\begin{array}{c}72.5 \\
(63.1 \text { to } \\
80.6)\end{array}$ & $\begin{array}{c}80 \\
\text { (22.8 to } \\
99.8)\end{array}$ \\
\hline \multicolumn{11}{|c|}{$\begin{array}{l}\text { TSB=Total Serum Bilirubin; } \mathrm{CL}=\text { Confidence Limits; } \mathrm{AUC}=\text { Area Under Curve; } \mathrm{p}=\mathrm{P} \text { value; } \\
+\mathrm{LR}=\text { Positive Likelihood ratio; }-\mathrm{LR}=\text { Negative Likelihood ratio; PPV=Positive Predictive Value; NPV=Negative Predictive Value. }\end{array}$} \\
\hline & & Table 5. Photo & therapy $P$ & $\begin{array}{r}\text { redictil } \\
\text { of } T\end{array}$ & $\begin{array}{l}\text { Utility of } 7 \\
\text { ne Since Bi }\end{array}$ & $\begin{array}{l}\text { Total Serum B } \\
\text { rth }\end{array}$ & ilirubin at $D$ & ifferent Poin & & \\
\hline
\end{tabular}

TSB in cord blood $>2.3 \mathrm{mg} / \mathrm{dl}$ and TSB at 24 hours $>5.3 \mathrm{mg} / \mathrm{dl}$ can satisfactorily estimate the probability of phototherapy need.

ROC curve analysis is done to know diagnostic (predictive) ability of TSB in cord blood to identify the need for phototherapy. The cut off value found is total serum bilirubin $>2.3 \mathrm{mg} / \mathrm{dl}$. Its sensitivity is $75.3 \%$ (95\% CL 65.2\% to $83.6 \%$ ), specificity $81.3 \%$ (95\% CL 72.6\% to 88.2\%), PPV is 77.8 (67.8 to 85.9), NPV is $79.1 \%$ (70.3\% to 86.3\%), positive likelihood ratio is 4.03 (95\% CL 2.7 to 6.1) and negative likelihood ratio is 0.3 (95\% CL 0.2 to 0.4 ).

ROC curve analysis to know the diagnostic ability of TSB at 24 hrs. to predict the need for phototherapy shows that TSB $>5.3$ $\mathrm{mg} / \mathrm{dl}$, has sensitivity of $87 \%$ (95\% CL $78.5 \%$ to $93.2 \%$ ), specificity of $67.3 \%$ (95\% CL 57.5\% to 76\%), Positive predictive value (PPV) of 69.8 (60.6 to 78.0), Negative predictive value (NPV) of 85.7 (76.4 to 92.4) positive likelihood ratio of 2.7 (95\% CL 2 to 3.5 ) and negative likelihood ratio of 0.2 (95\% CL 0.1 to 0.3 ). 


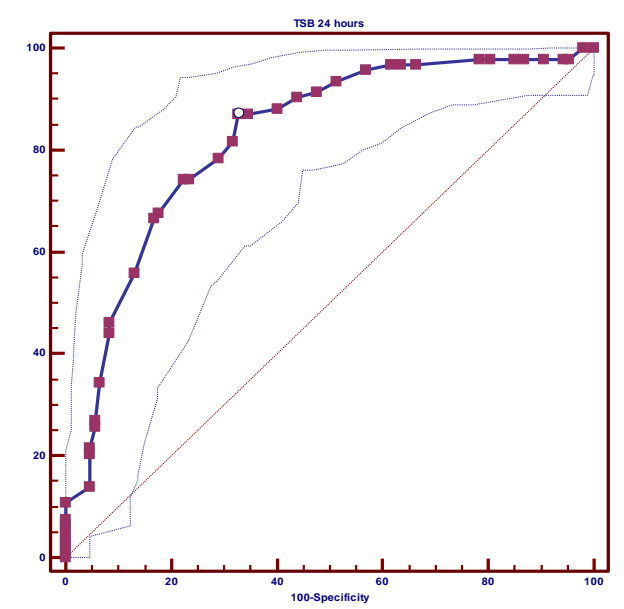

\section{Figure 1. Sensitivity and Specificity of Cord Blood TSB}

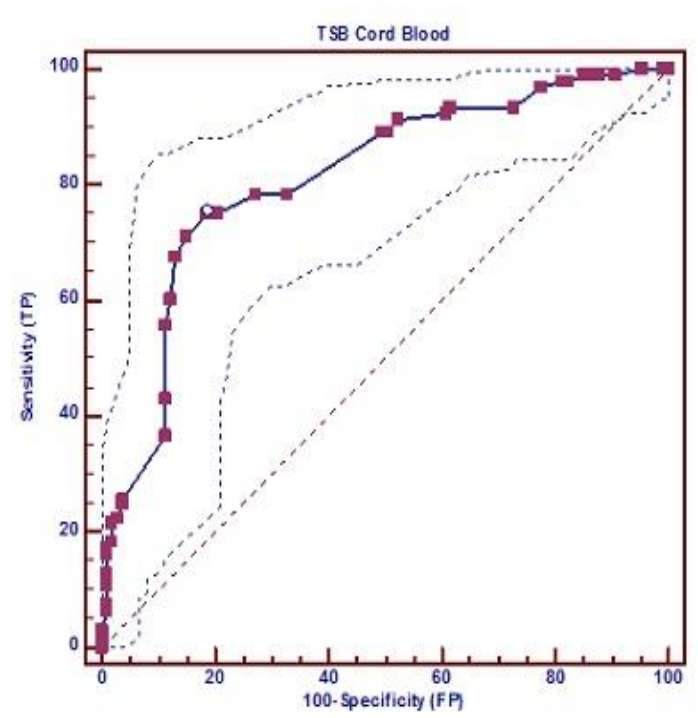

Figure 2. Sensitivity and Specificity of TSB at 24 hrs.

\section{DISCUSSION}

\begin{tabular}{|c|c|c|c|c|c|c|}
\hline Sl. No. & Author & Year & Sample & Population & TSB Cord & TSB at 24 Hours \\
\hline 1. & Present & 2013 & 200 & Healthy term & $\begin{array}{l}\quad \text { TSB }>2.3 \mathrm{mg} / \mathrm{dl} ; \\
\text { Sensitivity } 75.3 \% \text {; Specificity } \\
\text { 81.31\%; PPV 77.8\%; NPV 79\% }\end{array}$ & \begin{tabular}{|c|} 
TSB $>5.3 \mathrm{mg} / \mathrm{dl}$ \\
pensitivity $97.1 \%$, specificity \\
$67.3 \%$, \\
PPV $70 \%$, \\
NPV $85.7 \%$
\end{tabular} \\
\hline 2. & $\begin{array}{c}\text { Siwiluckkanchanabat } \\
\text { et al }\end{array}$ & 2010 & 289 & Healthy term & $\begin{array}{c}\text { TSB > } 2.3 \mathrm{mg} / \mathrm{dl}: \text { Sensitivity-14.6\%, } \\
\text { Specificity-91.3\%, PPV-25\%, NPV- } \\
84 \%\end{array}$ & ------- \\
\hline 3. & Zakia Naha et.al & 2009 & 200 & newborns & TSB $>2.5$ & ------- \\
\hline 4. & Sun G, Wang YL & 2007 & 523 & $\begin{array}{l}\text { Healthy } \\
\text { newborns }\end{array}$ & & ------- \\
\hline 5. & Amar Tisane et al & 2005 & 200 & Healthy term & $\begin{array}{c}\text { TSB > } 2 \\
\text { Specificity; 89.5\%; NPV - 98.7\%; } \\
\text { PPV-38.6\% }\end{array}$ & ------ \\
\hline 6. & Bernaldo AJ & 2004 & 400 & newborns & TSB $>2$ PPV $-53 \%$ & ------- \\
\hline 7. & Aage Knudsen et al & 1989 & 291 & & TSB > $2.35 \mathrm{mg} / \mathrm{dl}, \mathrm{PPV}-57 \%$ & ------ \\
\hline 8. & Rostani $\mathrm{N}$ et al & 2005 & 643 & Healthy term & TSB > 3 Specificity $92.4 \%$ & ------ \\
\hline 9. & ShivaniRandev et al & 2010 & 200 & & 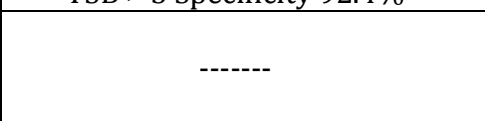 & $\begin{array}{l}\text { TSB }>6.4 \text {, Sen. } 87.5 \% \\
\text { Specificity } 80.11 \%, \text { PPV } \\
37.5 \%, \text { NPV } 98 \%\end{array}$ \\
\hline
\end{tabular}




\begin{tabular}{|c|c|c|c|c|c|c|}
\hline 10. & Rajesh Agarwal et al 18 & 2002 & 220 & $\begin{array}{l}\text { Healthy } \\
\text { newborns }\end{array}$ & ------ & $\begin{array}{c}\text { TSB >6 mg/dl, Sensitivity } \\
\text { 95\%, Specificity } 71 \% \text {, PPV } \\
27 \% \text {, NPV } 99.3 \%\end{array}$ \\
\hline 11. & X Carbonel et al & 2001 & 610 & & & $\begin{array}{c}\text { TSB }>6 \mathrm{mg} / \mathrm{dl} \text {, Sensitivity } \\
94 \% \text {, Specificity } 62 \%\end{array}$ \\
\hline 12. & Faro Allay et al & 2000 & 498 & Healthy term & ------ & $\begin{array}{c}\text { TSB > } 6 \mathrm{mg} / \mathrm{dl} \text {, Sensitivity } \\
90 \% \text {, NPV } 98 \% \text {, PPV } \\
26.2 \% 19\end{array}$ \\
\hline 13. & Sideman Ds et al & 1999 & & & & $\begin{array}{c}\text { TSB }>5 \mathrm{mg} / \mathrm{dl} \text {, Sensitivity } \\
63 \% \text {, Specificity } 94 \% .\end{array}$ \\
\hline 14. & ShallyAvasti et al & 1998 & 274 & & ------ & $\begin{array}{c}\text { TSB }>3.99 \mathrm{mg} / \mathrm{dl}, \\
\text { Sensitivity } 64 \% \text {, spe } 68 \%\end{array}$ \\
\hline
\end{tabular}

In the management of neonatal jaundice, a paediatrician comes across certain dilemmas. In routine practice, using standard guidelines of neonatal hyperbilirubinemia management, a clinician can take a decision whether a baby needs phototherapy or exchange transfusion only when the total serum bilirubin reaches certain critical levels. Thus, a clinician so far has therapeutic levels of TSB but not Phototherapy predictive levels of TSB for the management of neonatal hyperbilirubinemia. Hence there is a need to identify TSB values, at a much earlier time and lower than the critical therapeutic TSB levels, which have Phototherapy predictive ability. So, it helps to distinguish a baby who needs in hospital observation from a baby who can be sent home in a short time after birth. Results of our study show that it is possible to recognize a good predictive or diagnostic TSB value for identifying a baby that later needs phototherapy.

In our study, cord blood total serum bilirubin $>2.3 \mathrm{mg} / \mathrm{dl}$ is having a Predictive utility for the need for phototherapy, with sensitivity $75.3 \%$ (95\% CL $65.2 \%$ to $83.6 \%$ ) In Siwiluckkanchanabat study a cord blood TSB $>2.3 \mathrm{mg} / \mathrm{dl}$ has sensitivity of $14.6 \%{ }^{14}$. In a clinical problem like neonatal hyperbilirubinemia reliable prediction of a baby needing phototherapy is vital and the sensitivity of the test should be high so that babies who need phototherapy should not be missed. High sensitivity which may lead to prolonged hospitalization of some babies who may not actually need phototherapy for a few more days is preferable to low sensitivity which leads to discharge of a few babies who may need phototherapy after a few days. According to our observation, predicting need of phototherapy by cord TSB of $>2.3 \mathrm{mg} / \mathrm{dl}$ is likely to miss only $25 \%$ of babies who may need phototherapy, unlike in study of Siwiluck where the risk is very high.

In our study the total serum bilirubin at $24 \mathrm{hrs}$ of $>5.3$ $\mathrm{mg} / \mathrm{dl}$ is also useful in predicting the need for phototherapy with a sensitivity of $87.1 \%$ (95\% confidence limit 78.5 to 93.2). Ramesh Agarwal et al found that 24 hour total serum bilirubin $>6 \mathrm{mg} / \mathrm{dl}$ has sensitivity of $95 \% .{ }^{15}$ In Carbonel et al study 24 hour total serum bilirubin $>6 \mathrm{mg} / \mathrm{dl}$ has sensitivity of $94 \% 16$ FarukAlpay et al's study found a sensitivity of $90 \%$ with 24 hour total serum bilirubin $>6 \mathrm{mg} / \mathrm{dl} .{ }^{17}$ Shivani Ramdev et al found a total serum bilirubin $>6.4 \mathrm{mg} / \mathrm{dl}$ at 24 hrs is having diagnostic value with sensitivity of $87.5 \% .18$

ShallyAvasti et al in their study found a total serum bilirubin $>4 \mathrm{mg} / \mathrm{dl}$ at 24 hours is having a sensitivity of $64 \% .{ }^{19}$ In Seidman Ds et al's study, 24-hour total serum bilirubin $>5 \mathrm{mg} / \mathrm{dl}$ has sensitivity of $63 \% .^{20}$
This indicates that including our study many research workers find TSB of 24 hours is having higher sensitivity and more useful than TSB in cord blood in identifying a baby not needing phototherapy. As per our observation using the cutoff of TSB at 24 hours $>5.3 \mathrm{mg} / \mathrm{dl}$ may lead to missing about only $13 \%$ of babies who may need phototherapy. As per many others' observations risk of discharging a baby needing phototherapy is small if decision is based on TSB at 24 hours.

Bhutanivk et al's hour specific bilirubin nomogram facilitates a clinician in taking a discharge decision by predicting the possibility of subsequent neonatal hyperbilirubinemia basing on post-natal age (hours) specific serum bilirubin. At 24 hours a TSB of $5 \mathrm{mg} / \mathrm{dl}$ located at 40th centile curve of Bhutani's nomogram suggests a low risk of phototherapy and it corresponds closely with our phototherapy need predicting value of $>5.3 \mathrm{mg} / \mathrm{dl}$. Probability of phototherapy by our value $(5.3 \mathrm{mg} / \mathrm{dl})$ is $70 \%$. Bhutani's 75th centile TSB value suggestive of intermediate risk corresponds to nearly $6 \mathrm{mg} / \mathrm{dl}$ at 24 hours. As per our study the probability of phototherapy need is about $83 \%$ when TSB is $6 \mathrm{mg} / \mathrm{dl}$ at 24 hours. ${ }^{21}$

\section{CONCLUSIONS}

Most babies, who needed phototherapy, needed the intervention on $3^{\text {rd }}$ postnatal day. The time to reach maximum total serum bilirubin level after birth is 3 rd postnatal day. So, the baby in need of phototherapy has to be identified earlier to $3^{\text {rd }}$ postnatal day. A total serum bilirubin level prior to 3rd day which can predict the later need of phototherapy in a given baby will have clinical utility. Total serum bilirubin in cord blood and at $24 \mathrm{hrs}$ is having correlation with total serum bilirubin on $3^{\text {rd }}$ day. Temporally also total serum bilirubin in cord blood and at $24 \mathrm{hrs}$ are earlier values compared to total serum bilirubin on 2 nd day and helps in earlier prediction.

Hence, total serum bilirubin in cord blood and at $24 \mathrm{hrs}$ is evaluated for its ability to predict the need for phototherapy. The optimum cut off value of total serum bilirubin in cord blood which can predict the need for phototherapy is $>2.3$ $\mathrm{mg} / \mathrm{dl}$ and value of total serum bilirubin at $24 \mathrm{hrs}$ which can predict the need for phototherapy is $>5.3 \mathrm{mg} / \mathrm{dl}$. One can minimize risk of missing needed phototherapy by discharging a baby only when the likelihood or probability of phototherapy is very low. When a baby is healthy without any risk factors, a liberal cut off value of TSB can be used with a relatively higher likelihood of phototherapy, with an advice for follow up. The likelihood of need for phototherapy helps in advising frequency of follow up. Thus, all babies need not be in hospital, for considerable number of post-natal days, 
with its attendant risk of infection to the baby, if one has predictive TSB values suitable to one's hospital.

\section{REFERENCES}

[1] AAP Subcommittee on Neonatal Hyperbilirubinemia. Neonatal Jaundice and kernicterus. Pediatrics 2001;108(3):763-5.

[2] American Academy of Pediatrics Subcommittee on Hyperbilirubinemia. Management of hyperbilirubinemia in the newborn infant 35 or more weeks of gestation. Pediatrics 2004;114(1):297-316.

[3] Norr KF, Naocin K. Outcomes of post-partum early discharge, 1960-1986: a comparative review. Birth 1987;14(3):135-41.

[4] Bertini G, Dani C, Pezzati M, et al. Prevention of bilirubin encephalopathy. Biol Neonate 2001;79(34):219-23.

[5] Maisels MJ, Gifford K, Antle CE, et al. Jaundice in the healthy newborn infant: a new approach to an old problem. Pediatrics 1988;81(4):505-11.

[6] Palmer DC, Drew JH. Jaundice: a 10 year review of 41, 000 live born infants. Aust Paediatr J 1983;19(2):86-9.

[7] Kumar RK. Neonatal jaundice. An update for family physicians. Aust Fam Physician 1999;28(7):679-82.

[8] Manning D, Todd P, Maxwell M, et al. Prospective surveillance study of severe hyperbilirubinaemia in the newborn in the UK and Ireland. Arch Dis Child Fetal Neonatal Ed 2007;92(5):F342-F6.

[9] Ebbesen F, Andersson C, Verder H, et al. Extreme hyperbilirubinaemia in term and near-term infants in Denmark. Acta Paediatrica 2005;94(1):59-64.

[10] Smitherman H, Stark AR, Bhutani VK. Early recognition of neonatal hyperbilirubinemia and its emergent management. Semin Fetal Neonatal Med 2006;11(3):214-24.

[11] Behrman RE, Kliegman RM, Jenson HB. Jaundice and hyperbilirubinemia in the newborn. In: Nelson Textbook of pediatrics. $16^{\text {th }}$ edn. Philadelphia: Saunders 2000: p. 511-28.
[12] Dennery PA, Seidman DS, Stevenson DK. Neonatal hyperbilirubinemia. N Engl J Med 2001;344(8):58190.

[13] Clemons RM. Issues in newborn care. Prim Care 2000;27(1):251-67.

[14] Kanchanabat S, Boonyarittipong P, Kreinghirun 0. Prediction of hyperbilirubinemia in term newborns by umbilical cord blood bilirubin. Vajira Med J 2010;54(2):147-57.

[15] Agarwal R, Kaushal M, Aggarwal R, et al. Early neonatal hyperbilirubinemia using first day serum bilirubin level. Indian Pediatrics 2002;39(8):724-30.

[16] Carbonell X, Botet F, Figueras J, et al. Prediction of hyperbilirubinaemia in the healthy term newborn. Acta Paediatrica 2001;90(2):166-70.

[17] Alpay F, Sarici SU, Tosuncuk HD, et al. The value of first-day bilirubin measurement in predicting the development of significant hyperbilirubinemia in healthy term newborns. Pediatrics 2000;106(2):e16.

[18] Randev S, Grover N. Predicting neonatal hyperbilirubinemia using first day serum bilirubin levels. Indian J Pediatrics 2010;77(2):147-50.

[19] Awasthi S, Rehman H. Early prediction of neonatal hyperbilirubinemia. Indian J Pediatrics 1998;65(1):131-9.

[20] Seidman DS, Ergaz Z, Paz I, et al. Predicting the risk of jaundice in full-term healthy newborns: a prospective population-based study. Journal of Perinatology 1999;19(8 Pt 1)564-7.

[21] Bhutani VK, Johnson L, Sivieri EM. Predictive ability of a pre discharge hour-specific serum bilirubin for subsequent significant hyperbilirubinemia in healthy term and near-term newborns. Pediatrics 1999:103(1):6-14. 